\title{
The Politics of Land Redistribution and its Implications for the Effectiveness of Land Reform Programmes: Evidence from South Africa and Zimbabwe
}

\author{
* Sajjad Ali Khan, Assistant Professor \\ ** Abdul Shakoor, Assistant Professor \\ *** Ahmad Ali, Assistant Professor
}

\begin{abstract}
Land reform programmes around the world are often geared towards the accomplishment of a set of diverse goals. The process of land reform per se epitomizes a set of measures among which the redistribution of land among the poor takes center-stage and is generally regarded as the most consequential pre-requisite of an effective and successful land reform programme. This article seeks to examine the centrality of land re-distribution among the poor and the implications thereof for achievement of the broader set of goals through an analysis of land reform programmes carried out in South Africa and Zimbabwe. The findings demonstrate that in each of the two cases, the provision of land among the landless poor was overshadowed by political considerations during the process of distribution of land amongst the beneficiaries. The inequitable distribution in turn thwarted the accomplishment of the broader set of goals thus calling into question the effectiveness and success of such land reform programmes in each of the two countries.
\end{abstract}

Key words: Land reforms; Goals; land reforms measures; land distribution; South Africa and Zimbabwe

\section{Introduction}

Land reform programmes around the world are often geared towards the accomplishment of a set of diverse goals. Whereas state-led land reforms are often premised on the notion of economic and social justice, market-led reforms are often driven by demand and efficiency considerations and hence pay little if attention to the needs of the poor and the destitute (Sharma \& Jha 2016). The process of land reform per se epitomizes a variety of measures steered towards the achievement of the aforementioned goals. Among these, land

\footnotetext{
* Department of International Relations, Abdul Wali Khan University Mardan, Khyber Pakhtunkhwa, Pakistan Email: sajjadali@awkum.edu.pk

** Department of International Relations, Abdul Wali Khan University Mardan, Khyber Pakhtunkhwa, Pakistan Email: abdulshakoor@awkum.edu.pk

*** Department of Sociology, Abdul Wali Khan University Mardan, Khyber Pakhtunkhwa, Pakistan Email: abdulshakoor@awkum.edu.pk
} 
redistribution takes center-stage and more often than not serves as the most common idea underlying almost all land reform programmes. Notwithstanding the centrality of land redistribution, the lessons learned from land reform programmes earlier undertaken in different settings, however, transpire that the effectiveness and success of such reforms are often also contingent upon fulfillment of several other conditions such as an adequate institutional framework and programme design, robust implementation, appropriate selection of beneficiaries, supply of financial resources and other inputs and so on.

Empirical evidence concerning the implementation outcomes of a number of land reform programmes around the world, however, evinces that the effects of such reforms on the livelihood of the poor largely remain dubious (Barraclough 1992). Furthermore, land redistribution which essentially serves both as a means as well as an end in itself of majority of land reforms turns out to be either highly skewed or flawed at best. That is more often than not the process of redistribution of land among the landless seems to have been overshadowed by political considerations during the implementation process. In essence, any redistribution characterized by inequality and skewness calls into question the prospects of achieving the multiple objectives set out by proponent of land reforms. The inequitable and skewed redistribution thus give rise to a number of key questions such as; shall a land reform programme be regarded as successful if it achieves all the other objectives except an equitable redistribution of land among the landless poor? Can a proposed land reform programme successfully achieve the overall set of objectives without seriously taking into account an equitable redistribution of the restituted land among the poor segments of the population?

This article attempts to analyze land reform programmes undertaken in two southern African countries viz South Africa and Zimbabwe with a special focus being put on land redistribution among the poor, a common idea underlying almost all land reform programmes. The article's core argument is premised on the notion that the accomplishment of the broader set of goals set out by advocates of land reforms is largely contingent upon an equitable and transparent redistribution of land. Consequently, any land reform programme that falls short of redistributing land among the poor could barely address and solve at least the problems of poverty reduction, food security and social justice and may also offer implications for agricultural production and the overall growth as well. The redistribution of land among the poor, thus, takes center-stage in the reform process. Even if a reform process results in increased production and overall growth, the poor may still remain poor, disadvantaged and marginalized because of their exclusion from having access to land, a 
resource upon which their livelihoods largely hinge. Redistribution of land among the poor shall, therefore, take center-stage during the process of land reforms failing which the rest of the goals could barely turn out to be a dream come true.

The article is organized into four major parts. Part first attempts to spell out the (subtle) distinction between the two concepts; agrarian reform and land reform. Making a distinction between the two concepts is crucial because these concepts are often used interchangeably. Part second sheds light on the land reform programmes that unfolded in two southern African countries viz South Africa and Zimbabwe. Part three sheds light on the conditions that further help substantiate the land reform process. The final part of the article is dedicated to discussion and conclusion.

\section{Definitions of some Relevant Concepts}

\section{Agrarian reform and land reform}

According to Encyclopedia Britannica (2008), traditionally land reforms exclusively emphasized reforming the tenure system, the redistribution of the land and assignment of ownership rights. Over the years, the focus of reforms has further expanded to include the recognition of the strategic role of land and agriculture in development. Accordingly, the term land reform has come to be dubbed synonymously with the term agrarian reform which deals not only with the land tenure system but also emphasizes the patterns of cultivation, farm organization, the scale of farm operation, the terms of tenancy and the intuitions of rural credit, marketing, education and technology. According to Kuhnen (1971) agrarian reform refers to the set of measures purported to overcome the obstacles to development which ensue from flaws inherent in a given agrarian structure. This concept has come to prominence during the last ten years or so and has overshadowed the former concept of land reform. Thus, while 'agrarian reforms' epitomize a set of different measures ranging from reforming land ownership and farm organization and operation through to reforming land management, the term 'land reform' is used to describe measures such as restitution and the redistribution of land (Kuhnen 1982).

Agrarian reforms are often peddled to help achieve a variety of goals simultaneously. Empirical evidence, however, transpires that achieving all the goals at the same time turns out to be a tricky business. Quite often, the attainment of certain goals comes at the expense of others. Agrarian reform engenders a radical shift in the ownership structure of agricultural land. According to the Special Committee on Agrarian Reform, appointed by the Director General of FAO in 1969, agrarian reform entails "all aspects of the progress of rural 
institutions and covering mainly changes in: tenure, production and supporting service" (Ciparisse 2003).

According to Hanstad and Prosterman (2003), land reform comprises a set of measures that paves the way for the rural poor and the socially excluded groups to gain access to land as well as to exercise effective control over it. The Encyclopedia Britannica (2008) defines it as "a purposive change in the way in which agricultural land is held or owned, the methods of cultivation that are employed, or the relation of agriculture to the rest of the economy. Reforms such as these may be proclaimed by a government, by interest groups, or by revolution". Similarly, the term land reform is often also employed to denote the redistribution of property or rights in land for the benefit of the landless, tenants and farm labourers. This definition, however, is parochial since it considerably reduces the scope of the reform process to a single or only few elements of the entire reform process (Warriner 1969).

Redistribution, restitution and land tenure reform play out to be important types of land reform. Whereas redistribution entails distribution of expropriated land among the poor and landless, restitution serves both as a means to secure individual property rights as well as to provide financial compensation to individuals (Boyle 2000). The term land tenure reform is used to refer to the "system of rights (written and unwritten sets of laws) and institutions that govern access to and use of land" (Adams 2001). It may also refer to the terms and conditions under which land is held, used or transacted. Accordingly, land tenure security refers to an individual's right to have a piece of land and also being able to hold all the aces accruing from it (Bruce and Migot-Adholia 1994). Whereas tenure insecurity means the risk of losing individual's right to land as well as the benefits associated with land tenure security (UNECA 2004).

\section{Land Reforms in South Africa}

In the ex post of independence, the then South African Government promulgated an ambitious programme of land reform. The new land reform policy hinged on three major components: restitution; redistribution and tenure reform (CDE 2005; Cousins 2004; Government of South Africa 1997). The programme was state-subsidized at large that is it helped facilitated the black South Africans to get access to the financial resources required for purchasing land in existing land market, an approach highly influenced by the World Bank. It is important to point out that rural poor particularly women received little if any attention during the process of reforms. Consequently, the beneficiaries of reforms represented a constituent of black males at best (Macro Economic Research Group 1993). 


\section{Beneficiaries of the Reform}

According to Turner and Ibsen (2000), a critical analysis of the programmes launched by the Mbeki government such as the IPLRAD undergirds the notion that the entire land reform programme was not only characterized by internalization of the World Bank's views but also entailed the promotion of black commercial farmers and the exclusion of poor from the process of redistribution of land. Aliber (2001) notes that the number of rural African households is almost equal to 3.3 million of which one million households are chronically poor. Whereas the land reforms statistics demonstrate that since 1994 to August 2000, land was redistributed only among 37,000 households. Consequently, majority of the poor (over 96 percent) households did not capitalize on the reform process. The relatively insignificant number of the poor households which turns out to be the beneficiaries of the land reform belonged to relatively wealthy rural households (Deininger and May 2000).

Making a differentiation between the beneficiaries' and non-beneficiaries' of the reform process, Sender (2002) transpires that the number of beneficiaries' households owning cattle is 27 percent compared to African rural households where this number is only 15 percent. Similarly, among the beneficiaries, around 42 percent had access to electricity, 17 percent owned car and 19 percent had a telephone connection. Whereas among the nonbeneficieries' households only 26 percent had access to electricity, 8 percent claimed ownership to a car and only 5 percent had a telephone connection. Accordingly, Deininger and May (2000) assert that the World Bank's claim that the redistribution process was welltargeted towards the destitute turns out to be striking. While Cross and Hornboy (2002) note that the Bank labeled the land reform programme as gender anodyne on the grounds that around 31 percent of the surveyed beneficiaries' of the reform comprised female heads of households. A number of studies, however, evince that women, especially poor rural women benefited little if any from the land reforms. Despite the acquisition of land by female heads of the households, they were still grappling with the issue of security of the rights of ownership.

According to Deininger et al. (1999), yet another important factor that also underpins the notion that land re-distribution in South Africa was inequitable concerns the lower output or incomes accruing from the distributed land. A sample of 87 land redistribution projects demonstrates that the average profit per beneficiary was R161 (20\$). The lower levels of profit accruing from the land signify that the beneficiaries of the land reform had little if any interest in agricultural activities. In addition, the South African land reform programme also played a nominal role in the creation of wage employment opportunities for the poor. 
Empirical evidence suggests that the programme neither created opportunities for wage labor nor did the so-called reforms offered opportunities for absorbing unpaid family labor or wage labor. The available evidence shows a declining trend in wage labor since 1994. This trend is often attributed to the employers' fears of losing control over the land. Consequently, the land reforms undertaken in South Africa do not turn out to be pro-poor at large. That is the poor landless in South Africa suffered from the twin dilemma of being unable to acquire land as well as to lose the rural wage earning opportunities upon which their livelihoods hinged (Simbi and Aliber 2000).

\section{Land Reforms in Zimbabwe}

\section{The Land Reform and Resettlement Programme (LRRP)}

The Zimbabwean government's LRRP comprised two phases: the first phase was initiated in 1980 and ended in 1996 while the year 1997 marked the beginning of the second phase of the reforms. The post-independence Zimbabwean land reforms were steered towards redressing the discriminatory reform policies of past through the creation of equal opportunities in terms of both access to as well as ownership of land for majority of the Zimbabwean people. Furthermore, the reform process also purported to accomplish a variety of goals such as economic growth, food security, agricultural development etc. (Lebert 2006). The number of beneficiaries settled as a result of the land reform programme considerably varies in the ex post of independence. For instance, in 1980, the Government aimed to settle 18,000 households over a five years period. The year 1982 witnessed substantial increases in the number of households (almost 54,000) to be settled under the programme and later on it was fixed at 162,000 households, to be settled by 1984 . The first phase of the LRRP was premised on the principles of state-centered market-based land reforms approach, a two pronged approach entailing the purchase of land and the redistribution of such land (Lebert 2006).

\section{The Fast Track Land Reform (FTLR)}

The FTLRs in Zimbabwe were promulgated between 2000 and 2002. The FTLR which is generally regarded as a comprehensive package of reforms is also labeled by its critics as chaotic and controversial in nature. The FTLR was also primarily proposed to promote equity through poverty reduction and to redress the colonial legal framework largely characterized injustice and racial discrimination (Sachikonye 2003). It was completed in August 2002 and resulted in the distribution of land among 300,000 small farmers. Each small farmer was entitled with a land size ranging from 5 to 10 hectares. Apart from this, land was also distributed among 51,000 black commercial farmers. In the wake of implementation of FTLR, there was a considerable decrease in the number of white farmers. By the end of 2002, 
their number had decreased to only six hundred. During two and a half years, around 11.5 million hectares of land was re-distributed under the FTLR. The re-distribution was, in essence, an outcome of the government's efforts to devise special laws concerning both the acquisition as well as transfer of land (Sachikonye 2003).

\section{Beneficiaries of the Reform}

The Human Rights Watch (2002) maintains that some segments of population were outrightly ignored during the reform process. They included, for instance, landless farm workers, the descendents of Zambians, Malawians and Mozambicans, and women who had few rights to land under customary law. Among the rural women, those who served as seasonal or contractual farm workers were adversely affected by the FTLR (Amanor-Wilks 1996). According to UNDP (2002) the rural population of Zimbabwe is slightly larger than 8.5 million. As of November 2001, an estimated less than 236,000 families (both rural and urban) or at most 1.4 million people had benefited from the resettlement carried out during the last two decades. Adams (1991) and Cavendish (1999) have also raised eyebrows about the process underlying the selection of beneficiaries. They assert that more than 85 percent of the beneficiaries were men notwithstanding a colossal number of poor households in rural Zimbabwe do not have any adult male. According to UNDP (2002) another pitfall of the Zimbabwean fast track land reforms is its failure to put an end to the political clout and the control over land of existing powerful social groups on land, an important feature commonly shared by land reforms programmes carried out throughout most of African countries. The ramifications of inequitable land redistribution were consequential particularly for the poorest Zimbabweans.

Furthermore, the outcomes of FTLR in terms of crop production also turn out to be consequential. In the wake of reforms, the production of major crops such as maize, tobacco, wheat, soya beans, beef and horticulture witnessed a robust decline. A key reason underlying the observed decline is often attributed to the eviction of white commercial farmers which was further exacerbated by extreme drought conditions during 2001-02 and 2002-03. One of the key fallouts of the observed decline in crop production manifested in the form of food shortage crisis. The land reforms programme completely ignored the farm workers during the redistribution of process. Consequently, the loss of jobs, incomes, shelter and other basic social goods altogether made the farms workers even more vulnerable in the ex post of the reforms (Sachikonye 2003).

According to Johnston and Sender (2004), the Zimbabwean land reforms had played little if any role in the creation of employment opportunities particularly for the rural poor. 
The Farm Community Trust (2002) has also outlined the fallouts of the fast track land reforms for the seasonal workers. It maintains that by 2002, majority of the seasonal workers had lost employment. Prior to the execution of the FTLR in 2000, the number of farm worker households living on the farm was approximately 320,000. These households together constituted a population of 1 to 2 million of which 60 percent were poor. Once the land reforms were completed in 2002, it was observed that about two-third of the farm workers were deprived of their jobs and hence the opportunity to make a living. One of the major reasons for the loss of jobs is said to be the eviction of white farmers because the beneficiaries who replaced them were incapacitated in terms of creating job opportunities (Sachikonye 2003).

\section{Conditions (other than land) Essential for Successful Land Reforms}

The aforementioned analysis demonstrates that majority of the rural poor, seems to have benefited little if any from the land reforms carried out in both Zimbabwe as well as South Africa. That is to say that the poor not only failed to acquire a piece of land but also lost access to the existing farms as wage labor which adversely affected their income earning opportunities. This seems to be very much in line with the findings of Ghimire (2001) and Kay (1998) who argue that access to land continues to serve as the dominant issue notwithstanding the widespread adoption and implementation of land reforms. Verily, while the question of land is central to any land reform initiative, successful land reforms would, however, require more than just the availability of abundant of land for redistribution among the beneficiaries. Following are some of the factors which if taken into account may enhance the likelihood of success of any land reform initiative.

\section{Institutional framework, programme design and programme implementation}

Groenewald (2003) suggests that collaboration between public and private organizations serves as one of the key determinants of successful land reform programmes. The engagement process should not exclusively focus on organizations at any specific level of government. Rather, it shall attempt to emphasize to involve organizations at all levels of government. The same may also apply to private bodies. The engagement process may sometimes encounter problems such that different organizations at different levels may approach the reform process with a different sense of urgency. In a similar vein, the process may also be hampered by a lack of interest on part of bureaucracy. Such issues, however, can be fixed by coherently defining the roles and responsibilities of various departments at different levels. Groenewald further suggests that the framework for the design and 
implementation of land reform programmes shall be devised in collaboration with experts and public officials.

\section{Financial Matters}

According to Groenewald (2003), subsidizing government sponsored land usually requires huge amount of public money or otherwise the reforms may end in a chaos as was the case in Zimbabwe. Another relevant example is that of the Western Cape Province of South Africa where the reform process experienced retardation in 2003 because of the depletion of funds during the first half of the fiscal year. Proper fiscal planning may, therefore, be regarded as a pre-requisite of successful land reforms.

\section{Beneficiaries' Selection}

The success of land reforms also pivots on appropriate selection of beneficiaries failing which it is most probable to exclude the poor, the women, the dispossessed and the disadvantaged from the reform process. In so doing, one of the key goals of land reforms that is land redistribution among the poor will receive only a lip service during the reform process. From the analysis of the land reform programmes in both South Africa and Zimbabwe, it is evident that the poor, particularly the rural poor, women and wage workers, have benefited only marginally from the reforms both in terms of acquisition of land as well as other livelihood opportunities such as wage employment. This implies that the selection process of beneficiaries in both land reforms programmes was flawed at best. It is, therefore, important that the selection process is premised on a known criterion. The issue has received considerable attention and some scholars have sorted out certain criterion for beneficiaries' selection. For instance, Lewis (1954) asserts that beneficiaries should in first place be farmers with some knowhow of farming and should preferably be in possession of some personal capital. Burger (1971) had classified successful and unsuccessful farmers using a scale mainly based on 'managerial aptitude' with six different components. This scale was later on further developed (by Callow \& Groenewald 1993) to include other aspects such as marketing and purchasing behavior. Groenewald (2003) maintains that the same scale developed by Burger (1971) may be employed as a criterion for beneficiaries' selection with minor changes.

\section{Provision of Human and Financial Capital}

Giving a piece of land to a landless poor farmer and let him carry out the rest of the business himself may make things even worse. That is, the absence of the requisite skills and lack of capital may adversely affect their ability to get the most of out the land, a resource on which her/his livelihood largely depends. It is, therefore, advised that the land reform programmes 
are so designed as to have the financial capacity to provide beneficiaries with the basic agricultural skills as well as financial capital assistance.

\section{Supply of Inputs}

The success of the land reform programmes may also depend on a regular supply of inputs to the beneficiaries. Inputs may comprise a number of items ranging from highly sophisticated machinery such as tractor and so on to inputs such as pesticides and seeds. One of the dilemmas of most of the land reform programmes is to eschew the provision of inputs to the beneficial farmers.

\section{Adequate Compensation Paid for the Land Expropriated}

For the reform process to be smooth, it is imperative to compensate rather than to threaten those from whom land is expropriated for redistribution. Adequate compensation can in turn both help reduce the landowner's opposition as well as legitimize the reform. The feasibility of appropriate compensation mechanism, however, has decreased over the course of time because of the spiraling prices of privately owned lands and also because of the high population pressures on land (Hanstad and Prosterman 2003). In addition, other factors that may equally contribute towards the success of land reform programmes include for instance; having political will for the reforms, getting grassroots support for the reforms, infrastructure development and carrying out research on relevant issues that may emerge during the implementation and after the completion of each programme.

\section{Discussion}

As mentioned at the outset, land reforms usually entail more than just the redistribution of land among the poor. The redistribution, however, shall be carried out in an equitable and transparent manner failing which the reforms in question might fall short of achieving the broader set of objectives. The analysis in this article intuitively underpins this notion.

Both the South African and Zimbabwean cases share striking similarities (Peters \& Malan 2000). For instance, beneficiaries' selection in both the South African as well as Zimbabwean cases turns out to be flawed at best. For instance, contrary to the rhetoric that prompted the promulgation of such reforms, the reforms have barely accrued in giving the right of possession as well as ownership of land to the poor, the women particularly the rural women, landless farm workers, the dispossessed and the disadvantaged. The South African case reveals that beneficiaries' households were predominantly characterized as relatively wealthy rural households (Deininger et al. 1999). Furthermore, reforms in both countries may best be described as 'agrarian change' rather than 'land reforms' ((Peters \& Malan 2000). 
Another key issue that warrants attention concerns the repercussions of the land reform programmes for the casual and seasonal workers. Majority of the landless casual and seasonal workers who were dependent on wage earnings for survival lost their jobs in the ex post of reforms. This means that the land reform programmes in South Africa and Zimbabwe not only played a nominal role in the provision of land to the landless workers (poor) but also adversely affected their income earning opportunities, thus pushing them deeply into the vicious cycle of poverty. Finally, in the ex post of reforms, both South Africa and Zimbabwe witnessed a declining trend in agricultural production. In Zimbabwe, a considerable decrease was observed in the production of major crops i.e. tobacco, wheat, soya beans, beef and horticulture. This decline in crop production in turn ensued in food shortage (Sachikonye 2003). In a similar vein, the redistributed land projects in South Africa were also destined to witness a decline in the output either in the form of income or production (Deininger et al. 1999).

It is also evident that the land reform programmes in both countries have failed to a great extent to redistribute land among the landless. Furthermore, it also turns out that reforms in both countries were far from being able to foster agricultural production, enhance economic growth, reduce poverty, decrease food insecurity and maintain justice. Accordingly, this discussion tends to undergird the thesis that any land reform programme that would ignore the poor in the redistribution of land may prove ineffective in reducing poverty, ensuring food security, promoting agricultural production and so on.

\section{Conclusion}

The analysis in this article thus transpires that the South African and Zimbabwean cases share striking similarities particularly in terms of redistribution of expropriated land among the poor and landless segments of the population. The redistribution in both cases turns out to be skewed and unjust in both the cases such that a significant proportion of beneficiaries of the two land reform programmes predominantly belonged to those segments of population who were relatively well off. As such, the reforms seem to have excluded at large, the poor including landless workers, women particularly rural women, the disadvantaged and the dispossessed. In addition, the reforms have also adversely affected the livelihood opportunities (casual and seasonal work, other wage employment) of the poor. These findings in tandem with the observed decline in the crop production and hence a decline in prospects for ensuring food security imply that the land reform programmes in both the countries have encountered notable failures both in terms of identifying appropriate beneficiaries for the redistribution of land as well as addressing problems of poverty, food insecurity, crop 
production, social injustice and so on. The findings of this article intuitively contribute to our understanding of the salience of an equitable and just redistribution process. That is, as with other prerequisites, governments and policy makers alike shall put an overarching emphasis on devising mechanisms for making the redistribution process just and transparent.

\section{References}

Adams, J. (1991). The Rural Labor Market in Zimbabwe. Development and Change, 22 (2): 297-320.

Aliber, M. (2001). Study of the Incidence of Chronic Poverty and Development Policy in South Africa: An Overview. Programme for Land and Agrarian Studies in Conjunction with Chronic Poverty Research Centre. University of the Western Cape: South African Regional Poverty Network. htttp://sarpn.org.za/Country Poverty Papers/South Africa/policy.

Amanor-Wilks, D. (1996). Invisible Hands: Women in Zimbabwe's Commercial Farm Sector'. SAFERE, 2 (1): 37-57.

Barraclough, S. (1992). The struggle for land in the social dynamics of deforestation. In Fundacão Memorial da America Latina Conference (São Paulo, 25-27 March 1992), UMA Estratégia Latino-Americano para a Amazõnia, UNRISD, Geneva.

Boyle, H. (2000). The Land Problem: What Does the Future Hold for South Africa's Land Reform Program. Ind. Int'l \& Comp. L. Rev., 11, 665.

Bruce, J. W. \& Migot-Adholia, S. E. (1994). Searching for land tenure security in Africa. Dubuque, Iowa: Kendall/Hunt Publishing Company.

Cavendish, W. (1999). Empirical Regularities in the Poverty-Environmental Relationship of African Rural Households. Working Paper No. 99-21. Oxford: Centre for the Study of African Economies.

CDE (2005). Land Reform in South Africa: A $21^{\text {st }}$ century perspective. Research Report No.

14. The Centre for Development and Enterprise (CDE).

Ciparisse, G. (Ed.). (2003). Multilingual thesaurus on land tenure. Food \& Agriculture Organization: Rome.

Cousins, B. (2004). The Communal Land Rights Act: Likely to face constitutional Challenge.

Policy Brief. Programme for Land and Agrarian Studies, University of the Western Cape, Cape Town.

Cross, C. and Hornby, D. (2002). Opportunities and Obstacles to Women's Land Access in South Africa. A Research Report for the Promoting Women's Access to Land Programme. National Land Committee. http://www.nlc.co.za/pubs2003 
Deininger, K. and May, J. (2000). Can There Be Growth with Equity? World Bank Policy Research Working Paper No. 2451. Washington, DC: World Bank.

Deininger, K., Naidoo, I., May, J., Roberts, B., \& van Zyl, J. (1999). Implementing "MarketFriendly" Land Redistribution in South Africa: Lessons from the First Five Years. In Global Development Network Conference. Bonn, Germany: World Bank.

Encyclopædia Britannica (2008). Land Reform. Encyclopædia Britannica Online. http://search.eb.com/eb/article-9106469

Farm Community Trust (2002). Report on Assessment of the Impact of Land Reform Programme on Commercial Farm Worker Livelihoods. Highlands, Zimbabwe: Farm Community Trust of Zimbabwe.

Ghimire, K. (Ed.) (2001). Land Reform and Peasant Livelihoods. London: ITDG; Geneva: UNRISD.

Government of South Africa (1997). White Paper on South African Land Policy, Department of Land Affairs, Pretoria.

Groenewald, J. A. (2003). Conditions for Successful Land Reform in Africa. Paper Presented at Pre-IAAE Conference in African Agricultural Economics. Bloemfontein, South Africa, August 13-14, 2004.

Hanstad, T. \& Prosterman, R. L. (2003). Land reform in the $21^{\text {st }}$ century: New challenges, new responses. RDI Reports on Foreign Aid and Development No. 117. Rural Development Institute.

Hall, R., Kleinbooi, K., \& Mvambo, N. (2002). What land reform has meant and could mean to farm workers in South Africa. Centre for Rural Legal Studies.

Human Rights Watch, (2002). Zimbabwe: Fast Track Land Reform in Zimbabwe. Human Rights Watch, 14 (1): 1-44.

Johnston, D., Sender, J. (2004). Searching for a Weapon of Mass Production in Rural Africa: Unconvincing Arguments for Land Reform. Journal of Agrarian Change, Vol. 4 Nos. 1 and 2, January and April 2004, pp. 142-164.

Kay, C. (1998). Latin America's Agrarian Reform: Lights and Shadows. Land Reform, Land Settlement and Cooperatives, 2: 9-31.

Kuhnen, F. (1982). Man and Land, Saarbrücken and Fort Lauderdale.

Kuhnen, F. (1971). Land Tenure and Agrarian Reform in Asia. A Re-appraisal of Priorities in Agrarian Reorganization for Rural Development. Revised version of a paper for the Asian Regional Seminar on the Contribution of Rural Institutions to Rural 
Development, Particularly Employment, organized by the International Labour Organization, New Delhi, 3rd to 16th November 1971.

Lebert, T. (2006). An Introduction to Land Reform in Zimbabwe (Chapter 2). In Rosset, P.

Patel, R. and Courville, M. (Eds) (2006). Promised Land: Competing Vision of Agrarian Reform. Food First Books: California (USA).

Lewis, W. A. (1954). Thoughts on land settlement. Journal of proceedings of the Agricultural Economics Society, 11(1), 3-19.

Macro Economic Research Group (1993). Making Democracy Work: A Macroeconomic Policy Framework for South Africa. Cape Town: MERG.

Peters, B. L. \& Malan, N. (2000). Caveats for land reform in South Africa: Lessons from Zimbabwe, South African Journal of International Affairs, 7:2, 151-161, DOI: $10.1080 / 10220460009545323$

Sachikonye, L. M. (2003). Land Reform for Poverty Reduction? Social Exclusion and Farm Workers in Zimbabwe. Paper Prepared for a Conference on "Staying poor: Chronic Poverty and Development Policy. Organized by the IDPM, Manchester University, April 2003.

Sender, J. (2002). The Struggle to Escape Poverty in South Africa: Results from a Purposive Survey. Journal of Agrarian Change, 2 (1): 1-49.

Sharma \& Jha (2016). Land Reform Experiences: Some Lessons from Across South Asia. A Research Document Prepared for the World Forum for Access to Land 2016. The Food and Agriculture Organization of the United Nations.

Simbi, T. \& Aliber, M. (2000). Agricultural Employment Crisis in South Africa. TIPS Working Paper No. 13_2000. Johannesburg: Trade and Industrial Policy Secretariat.

Thiesenhusen, W. C. (1996). Trends in Land Tenure Issues in Latin America: Experiences and Recommendations for Development Cooperation. GTZ, Eschborn.

Turner, S., \& Ibsen, H. (2000). Land and agrarian reform in South Africa. A status report. Research Report-Programme for Land and Agrarian Studies, University of the Western Cape, (6).

UNDP (2002). Zimbabwe Land Reform and Resettlement: Assessment and Suggested Framework. United Nations Development Programme for the Future. New York: UNDP.

UNECA (2004). Land Tenure Systems and the Impacts on Food Security and Sustainable Development in Africa. ECA/SDD/05/09. Addis Ababa. 
Warriner, D. (1969). Land reform in principle and practice. Clarendon Press: Oxford. ISSN: $1356-9228$ 